Article

\title{
Principles for Integrating the Implementation of the Sustainable Development Goals in Cities
}

\author{
Robert Weymouth * and Janette Hartz-Karp \\ Curtin University Sustainability Policy Institute, Perth 6102, Australia; J.Hartz-Karp@curtin.edu.au \\ * Correspondence: robert.weymouth@postgrad.curtin.edu.au
}

Received: 23 July 2018; Accepted: 23 August 2018; Published: 27 August 2018

\begin{abstract}
The implementation of the UN's Sustainable Development Goals in the urban centres of the world is one of the most consequential and ambitious projects that the nations of the world have undertaken. Guidance for achieving the goals in an integrated way that creates true sustainability is currently lacking because of the wicked nature of the problem. However, its wickedness highlights the critical importance of governance and decision-making processes for such integration, including the relationship between governments and their citizens. In particular, there is strong evidence to suggest that managing wicked problems like the SDGs is best done through forms of democracy that are deliberative, representative and influential. Called "deliberative democracy", we draw on an existing body of research and case studies of deliberative democracy in action to apply its principles to a step-by-step process for the implementation and integration of the Goals in Cities. The paper concludes with the beginnings of a framework based on deliberative democratic principles, and an outline of methods for the scaling and expansion of the implementation process to cope with the global nature of the problem.
\end{abstract}

Keywords: sustainable; development; goals; deliberative; democracy; wicked problem

\section{Introduction}

In 2014 the majority of the world's population-more than 54 percent-lived in cities and by mid-century, this figure is expected to rise to two out of every three human beings on the planet [1]. Meeting the Sustainable Development Goals (SDGs), adopted three years ago by the UN [2], will be critical to ensuring that this radical change does not produce human crises that overwhelm the ability of member states to cope with them.

Early thinking about sustainability assumed the need to recognise trade-offs between demographic, economic (including consumption and technology), environmental, and social/cultural factors. Now the focus has shifted to the need to achieve sustainability "... through the integration and acknowledgement of economic, environmental, and social concerns throughout the decision making process" [3]. Though the question of how to realise such integration has received some attention [4], it is unclear how public decision-making processes might be transformed to generate outcomes that support and advance this aim.

In this article, we propose an approach to bridging the strategic gap between the substantive policy goals for long-term sustainability and the means that will be required to attain them. Specifically, we outline a series of principles for achieving the integrated implementation of SDGs in cities, based on the scaling of collaborative problem solving and decision-making. The methodology underlying this framework is "deliberative democracy" (i.e., democratic decision-making that is representative, deliberative, and influential). We discuss several case studies from around the globe in order to illustrate the potential of the proposed framework. 


\subsection{The Importance of Integrating the SDGs}

The SDGs—involving 17 goals with 169 milestones and 232 indicators [5]—represent a positive start to serious efforts to achieve sustainability. Many of the goals focus on broad outcomes such as the mitigation of poverty, hunger, and human-generated climate change. All SDGs will affect human settlements, and more than a third will have a direct impact on urban development [6,7]. Goal 11 (along with its 11 targets) specifically calls for "inclusive, safe, resilient and sustainable cities" in the context of the large and growing percentage of people who reside there and where the majority of both GDP [8] and energy [9] are generated.

The pitfalls of the SDGs have been highlighted [10], especially in cities [11], but there is growing consensus about the importance of integrating the SDGs [12]. Reasons supporting integration abound, including not just the efficiencies it would generate, but also recognition of the interdependent nature of the SDGs and the inescapability of trade-offs. Thus, certain goals may be achieved more easily or synergistically if pursued along with others. For example, providing sanitation is likely to improve economic output [13]. In contrast, recent reviews of the goal indicators show that consumption levels, banking secrecy, tax havens, and weapons exports by rich countries may be inhibiting development in poorer countries [14]. Additionally, we argue that though the nature, definition, and practice of sustainability is contested $[15,16]$, if the goals cannot meet all the commonly accepted criteria for sustainable development, the results will be neither stable nor lasting. In our view, the best route to achieving all SDGs in the most effective ways is via their integration throughout the implementation process.

The case for integrating SDGs has received support not just from theory [17], and modelling [18], but from practical experience. For example, American cities that have been most successful in achieving the SDGs have integrated the goals throughout their existing planning and business operations. [19]. Yet despite this support-plus 11 of the indicators being duplicated across multiple goals, and the creators of the SDGs noting the need for their integration [2] - little progress has been made on frameworks and processes to achieve integrated outcomes $[13,20,21]$.

\subsection{The Difficulties of Integrating the SDGs}

Understandably, it might be thought that, like many problems in the natural sciences (though less so in the social sciences), the sustainability "problem" can be broken into a finite number of pieces that can be solved discretely and then aggregated to arrive at a successful overall solution. The SDGs, however, address a class of problems that are ill suited to this atomistic and reductionist approach [22]. These problems have been labelled "wicked" and the SDGs qualify as some the most wicked problems facing us [23,24].

Identified initially in planning policy [25], "wicked" problems have now been diagnosed widely in almost every aspect of sustainability [26]. Wicked problems are ill defined, nonlinearly linked, and subjectively viewed. Their converse, the "tame" problem, is one that can be solved by adhering to an established, "tried-and-true", "linear" process of analysis, identification of options, and cost-benefit analysis. Such problems are straightforward-they quickly suggest one or more solutions-even if devising the solution requires a great deal of time and other resources. Tame problems tend to be insulated from the effects of the external environment. Owing to this insulation, they can be "complex" (i.e., composed of many interacting elements (most of them internal)), and yet remain likely to yield a broadly acceptable solution with time and persistence. A wicked problem, in contrast, cannot be solved in a manner that is straightforward, familiar, and "linear". As the originator of this term, Horst Rittel [25], defined it; a wicked problem is distinguished by the following characteristics:

- The problem cannot be understood fully until a solution has been proposed: Every solution to a wicked problem reveals some new aspect of it that requires further adjustments to what has been proposed. This means there is and can be no definitive statement of "the problem". The problem is "ill-structured"-it is composed of interrelated influences, constraints, and effects that vary 
with the context in which it is encountered. What "the problem" is depends on the perspective from which an answer to the question is offered; different stakeholders have fundamentally different views about what constitutes the unsatisfactory condition that constitutes the problem and warrants a response.

- There is no clear and uncontested rule for determining when to stop the effort to identify and respond: Because there is no definitive conception of the problem, there can be no definitive solution. The problem-solving process concludes when participants run out of resources-time, money, energy - and is judged to be either "better" or "worse".

- Solutions are not right or wrong: Since no clear, consensual criterion of success exists, solutions offer outcomes that are only "better", "worse", "good enough", or "not good enough". The adequacy of a solution depends on perception of the problem and so stakeholders assess possible solutions from within their respective organising belief systems ("worldviews").

- Every wicked problem and solution is novel and unique: For every wicked problem, large numbers of contributing factors are embedded in a constantly-changing social context. For this reason, problems are unlikely to have been encountered previously, at least in precisely the same form. Each differs substantially from others, making every wicked problem unique. To make things worse, every attempt to solve a wicked problem has consequences that preclude its replication. People cannot learn about the problem without trying solutions, but every solution tried is costly and produces consequences that, intended or not, are apt to generate additional problems.

- The problem is consequential and there is no single clear solution: The effects of the problem are impactful and significant and so are the effects of the solution. Those facing wicked problems, as Rittel says, "have no right to be wrong". Compounding this, it is possible that there may be no solution at all. Or there might be many solutions, none of which can be usefully compared to the others. Or there might be solutions that are never thought of. Devising any viable solution requires imagination and creativity. Settling on one requires judgment.

These characteristics make wicked problems highly resistant to the linear problem-solving attempted in a centralised, top-down, "command-and-control" structure, populated by a limited number of persons whose perspective is technocratic, bureaucratic, or politically partisan and competitive. Dealing effectively with this complexity requires that the relationships between the parties be taken just as seriously and treated just as skilfully as any other factor that is relevant to solving the problem. Both direct and indirect stakeholders must be included in a "meaningful way" in the effort to solve the problem. While there may be a "best" answer for all concerned, there is no single "correct" one. Rather, what matters is whether everyone whose buy-in is needed to devise and implement a solution supports the course decided upon. "To put it more starkly", writes Conklin, "without being included in the thinking and decision-making process, [stakeholders] may seek to undermine or even sabotage the project if their needs are not considered" [27]. The antidote is a problem-solving approach that is non-linear, de-centralised, bottom-up, maximally inclusive, diversely constituted, cooperative, and, recognising the importance of relationships, is orientated to the achievement of a solution that is acceptable to all. Overcoming fragmentation requires sharing: shared knowledge, shared understandings, shared priorities, shared responsibilities, shared effort, shared goodwill, and shared commitment.

In view of the limitations of both centralised, top-down, "technocratic" problem-solving and self-interested political competition, it seems prudent to prioritise alternative approaches to solving wicked problems

\subsection{Reforming Governance: Key to Integrating the $S D G^{\prime}$ 's}

Addressing problems in the public sphere and how decisions should be made to resolve them is the domain of governance. [28,29] Governance was considered but not included as a stand-alone SDG 
because of its politically charged nature. Although we agree with the normative aspects of the method we outline here, our arguments in support of it will follow the SDG's implicit approach to governance as an enabler for the Goals rather than as an end in itself. Not surprisingly, a growing literature has emerged detailing the failure of existing modes of national governance to solve wicked problems, and emphasising the need for alternative approaches that are less reductionist and more integrative [30,31]. The concept of governance as a mode of social cooperation between social institutions has been discussed at length in recent years [12]. Considerable disagreement exists, however, concerning the answers to, and relative importance of three basic questions about the decision-making process: Who decides (input)? How do we make decisions (process)? and What happens when we decide (output)? [32].

Following on from our discussion above of their wicked nature, the elements of governance most likely to be needed in efforts to integrate and implement SDGs successfully are as follows:

- Collective Value Judgements: SDGs are intimately linked to a series of value judgements-not just those of individuals, but also public ones that must be formed collectively [33]. How to make such value judgements is essential to the legitimacy of a sustainability governance model. However, forty years ago Rittel commented: "We do not even have a theory that tells us how to find out what might be considered a societally best state." [25]. Fortunately, since this time there has been much theorising and research on legitimate methods for arriving at socially constructed judgements [34,35]. This governance element informs questions of input and process, and highlights the need to create a legitimate way of elevating the values of importance to each of the SDGs.

- Diverse inputs: The uncertainty that attends the diagnosis and resolution of wicked problems means that effective SDG decision-making will resist a purely technocratic approach [22]. It has been shown that attempts to do this by removing politics and value judgments results in de-emphasising important aspects of urban sustainability [16]. While the scientific, evidenced-based perspective is necessary [36], it must take the form of "map making", not "navigating" [23]. Multiple domains of knowledge (e.g., science, traditional, lay, managerial) will have to be brought to bear in the service of sustainability [37]. Over-determining the optimal number and mix of perspectives is also problematic, both because doing so presumes a complete grasp of the boundaries of the problem [38] and also can reduce diversity [39]. While this element shapes the answers to the input governance question, it also shapes the process, in that it dictates that the method for decision-making must invite and elicit the required diversity.

- Deliberative Communication: Prescriptions of the preferred communication mode elucidate the process nature of governance questions. The most conducive mode of problem-solving and decision-making around wicked problems [40] and particularly sustainability issues, tends to be a "deliberative" one [16,41]. Deliberation is a form of communication involving the exchange of reasons between persons representing different political "discourses" (perspectives, worldviews, etc.); rational reflection; and the public justification of possible solutions, with the aim of coming to resolution or action. Deliberative discussion can confer greater legitimacy [42] and exhibits greater epistemic strength than alternatives [43]. This makes deliberation well matched to the deeply contested nature of sustainability issues [44].

- Distributed and Collaborative Power and Action: It is widely acknowledged that distributed and collaborative power will be important to making significant progress toward sustainability [44-46]. Centralised, "top-down" policy-making approaches have been rejected in various quarters, including the UN itself, which recommends collaboration and localisation of the SDG's. (" ... All stakeholders, acting in collaborative partnership, will implement this plan.") [2]. Competitive mechanisms are viewed with scepticism, especially in light of the well documented failure of markets to achieve improved sustainability [47], and the critique of them as a driver of the current sustainability crisis $[48,49]$. Acknowledging the general unsuitability of market mechanisms for solving sustainability problems does not preclude use of them (or on "top-down" directives) 
as a tool for harnessing support for some goals in some cases. Nevertheless, a collaborative approach to wicked problems is desirable precisely because it is important to "make those people who are being affected into participants of the planning process. They are not merely asked but are actively involved in the planning process" [50]. Engendering such collaboration goes to the process governance question of how decisions are made, but it also has a clear implication of actual influence and power being vested in the outcomes of the collaborative process, rather than an interesting, but hollow discussion (output). This principle is evident in the recent trend toward decentralisation of the SDGs, i.e., implementing them at the local municipal level, where decision-makers are "closer to the people" [51,52]. Even in undemocratic nations, there has been a preference for local implementation [53].

We contend that the governance model that has the greatest potential to satisfy these foregoing sustainability governance requirements is deliberative democracy [54]. Deliberative democracy is characterised by reason giving discourse between everyday people in an egalitarian environment, with the outcomes being influential on government policy or action. It is a political philosophy with roots in the enlightenment, which has undergone intensive research and practice over the past three decades, morphing into an increasingly accepted alternative for democratic decision-making $[55,56]$. We situate ourselves in this theory continuum with modern theorists [57] who hold to the communicative ideals of Habermas, but accept the need to balance agonist and consensus modes [58] with a freer conception of valid discursive types [59].

Three key governance principles differentiate deliberative democracy from community consultation, "empowered" community engagement, and other forms of democracy and citizen participation [60]. Listing these principles also conveniently allows us to compare them to the governance principles we described above that will implement and integrate the SDGs:

- Deliberation/Weighing: Participants in a deliberative democratic process weigh reasons and arguments for and against competing options using rationality and shared values [61]. In the service of some "common good" the group seeks to arrive at a publicly justified decision or conclusion that is based on the shared judgment that the preponderance of such reasons and arguments favours one option over another. While the search for common ground is important, reaching consensus is desirable but not essential [62]. This principle of deliberation/weighing is no more than the deliberative communication element of the SD governance. In practice, the deliberative ideal can be approached in a number of ways. A wave of research over the last two decades [63], demonstrated how this principle could be achieved through elements of design and execution. Two elements were particularly relevant. The first was the use of randomly selected citizens who often knew little about the topic under deliberation or were politically inactive, but could clarify the values they held dear. This was found to be advantageous to deliberation because participants were not cognitively or emotionally anchored to a position and hence were open to potential attitude shifts on the topic [64]. Being selected by lot also increased their democratic legitimacy - they were seen to have no vested interests. The second element was the inclusion of stakeholders involved in, or affected by, the issue being deliberated, whose expertise and buy-in would be important. Stakeholders with particular expertise and perspectives, including those with credentials and others with community wisdom, can be included in the deliberations in a number of ways other than as members of the deliberating group. This included: becoming members of deliberation overseeing committees to vet information and decision rules for neutrality; contributing position papers on their perspectives; presenting their views and being cross-examined by deliberators; and/or being invited to observe the proceedings. The broader public can also be invited to participate in numerous ways such as being asked to suggest options, present them to the deliberators and respond to their questions; discuss draft recommendations with the deliberators; and/or observe the deliberation process through webcasting or as live audience Such contributions are an important element of high quality deliberation [65]. 
- Representation/Inclusion: As a form of democracy that pays particular attention to the deliberative communication mode, representation is important to deliberative democracy for two main reasons. Firstly, as a form of democracy, the legitimacy claim to decide on behalf of a "demos" is definitional. Secondly, the deliberative desire to weigh all arguments and perspectives on an issue of importance to a "demos" drives a search for inclusion of those perspectives as another claim to (deliberative) legitimacy [66]. These are the propelling reasons behind the preference for descriptive representation of a population when selecting participants for a deliberative governance process. This is contrasted with the substantive representation common in most electoral democracies where an elected candidate advocates for a constituency based on a pre-set policy agenda. Descriptive representation chooses representatives based on relevant political attitudes that often manifest in demographic characteristics (e.g., age, gender, socio-economic status etc.). Random selection (often with stratification for demographic characteristics to maximise representativeness) is the most common method of achieving a decision-making group who reflect the diversity of outlooks (worldviews) within the general population. This diversity directly contributes to the input diversity that is an important element of governance capable of integrating the SDGs. Additionally, such representativeness brings with it a claim of deliberative legitimacy. This legitimacy boosts the claim that any decisions from the decision-making (process) were made collectively for the common good, since the group descriptively resembles the collective. That claim can then increase the likelihood of influence and action following the deliberative decision-making by the collaborative group (output).

- Influence/Impactfulness: Although deliberative democracy is known for its focus on a particular form of political communication, it remains a form of democracy, and consequently its outputs must have influence on the governance of a group of people. This influence is sometimes a delegation of power, but most deliberative forums take place in the context of existing power structure and statutes and usually have to take account of this. For example, the Citizens Assemblies of British Columbia and Ontario recommended changes to their constitutions that required a referendum to pass and while they were narrowly defeated they were successful within their own terms of producing a measure to be voted on by the populace as a whole [67]. Such influence can often have downstream effects, like in the case of the Irish Constitutional Convention [68] that some have argued was a key initiator of a later, successful abortion referendum [69]. In practice, it has been found that a prior commitment by official decision-makers enables participants to exert influence-and to be seen as exerting influence-on policy development and decision-making about the matter being deliberated. This commitment can stretch from serious consideration of recommendations with a public response, through to implementation through referendum with many ways of being influential.

These principles clearly show that deliberative democracy incorporates the desired governance characteristics best fitted to addressing the wicked problem of integrating the SDGs described above. Although related, we distinguish participatory democracy as a governance system that is best fitted to integrating the SDGs from deliberative democracy. We appreciate the emphasis of participatory democracy on the broad involvement of constituents in a political system if a wicked problem is to be resolved; indeed, in Section 3 we advocate for scaling governance of implementation of the SDGs to as many constituents as is feasible. However, it is the lack of focus on deliberation and collaboration in participatory democracy that in our view, makes it an inferior choice when compared to deliberative democracy as a form of governance to integrate and implement the SDGs. In spite of believing deliberative democracy as a governance system is well matched to the challenge of implementing the SDGs, it is not without its shortcomings. Despite its successful implementation in many countries and improvements in methodology, it has yet to be scaled (both vertically and horizontally) and institutionalised [70]. The need to scale initiatives to improve their scope and reach, while addressing higher levels of complexity, has had only limited success. Retaining high-quality deliberation and containing costs have proved difficult. Institutionalisation has also been problematic, in part because 
most existing democratic power structures inherently limit the potential for co-decision-making between elected officials and their constituents, and in part because power is rarely conceded voluntarily. Fortunately, these shortcomings are not insurmountable and do not preclude the use of deliberative democracy in this context. We are not alone in this conclusion, with others identifying it as a viable option for earth systems governance [71,72], and showing it to be effective in discrete SDG implementation in terms of prioritisation [13], consistency, and rational choice [73]. However, because this approach holds such potential to effectively address wicked problems and successfully integrate the SDGs, we hold that it is likely to play a pivotal role in future efforts to realise the latter $[4,12,74]$.

\section{A Model for Achieving Integrated SDGs in Cities}

Having established the value in a deliberative democratic approach to integrating the implementation of the SDGs, we now move on to a practical application of this approach in urban environments. The official road map for achieving the SDGs in urban environments, "Getting Started on the SDGs in Cities" (which we will refer to as the "Guide") [51] outlines a four-step process:

1. Initiate an inclusive and participatory process of SDG localisation: including awareness raising, multi-stakeholder involvement, strong leadership, and integrated governance.

2. Set the local SDG agenda: equipping the SDGs with ambitious but realistic local agendas, evidence-based decision-making, and public involvement.

3. Plan for SDG implementation: using goal-based planning, both long-term and multi-sectoral, and supporting it with financial resources and partnerships.

4. Monitor SDG progress: by measuring progress and gains in program efficiency using disaggregated data systems, local monitoring, and evaluation that develops local capacity and enhances responsive and accountable governance.

The Guide offers little advice on how to carry out these tasks. Decision-making processes are left vague and ambiguous. It is unclear "who gets to decide", "what process is to be used for decisions", and "what happens when the decision is made". While there are hints that these steps should be "participatory and inclusive", neither a rationale nor instructions are provided (the Guide does provide in boxes a list of potential stakeholders and examples of participation throughout, but there is no exploration of deeper theory or a framework linking and explaining the examples).

To address these inadequacies, the following framework reformulates the four tasks above using the principles of deliberative democracy in order to include enhanced deliberation, representation and influence, while preserving the overall Guide's structure. We offer reasons for this reformulation, and support them with reference to case studies. A note of caution: Implementation and integration of the SDGs is not only a wicked challenge-it is an undertaking unique in human history. There exists little reliable data to draw on in supporting our contention that the governance model we propose affords us the best chance to implement and integrate the SDGs successfully. This is an artefact of the nature of wicked problems discussed in Section 1 and its uniqueness and its shifting nature. Consequently, any overly prescriptive formula or detailed plan would either become rapidly outdated or inapplicable to particular cases. With this in mind, we believe the general application of principles and the illustration of those principles in action in a case study is the most viable approach. This does not mean that scientific principles and rigour should be abandoned, but only that a measure of humility is needed to allow for flexibility, action learning, and reflection and revision.

\subsection{Commit to and Prepare for Localised SDG Deliberative Democratic Processes}

While deliberative democratic governance processes are important for resolving cities' wicked unsustainability problems, such processes cannot be established and maintained within the usual structures through which government officials acquire their authority and exercise their "power over" people, permitting citizens to "have their say", but keeping "the last word" for themselves. Public servants must put the "service" back into their job descriptions, and agree to explore ways of exercising 
"power with" people-committing not only to the principle of citizen empowerment, but allowing citizens to influence the decisions that are made.

Choosing the appropriate degree of influence can be facilitated by referring to spectrums of participation that have been much discussed and modified [75-77]. Different parts of the process may allow for different levels of participation and influence. Clarifying the level of influence is important for two reasons. First, as noted previously, shared responsibility and authority are highly desirable in efforts to resolve wicked problems. Second, survey research from the USA [78] and Australia [79] has shown that citizens prefer a "partnership" relationship with their government rather than an increase in empowerment. They want neither complete control nor marginal consultation, but rather a decision-making process that is respectful of the strengths, resources and experience of ordinary people in combination with the experience and knowledge of elites, and the learning that goes with both. In view of the continuing widespread decline in trust in western democratic governments [80,81], pursuing this aim would do much to restore public trust. Third, a greater level of citizen influence rules out a "business as usual" approach in which decision-making is considered to lie exclusively within the purview of elected representatives. Restricting citizen participation to "inclusion" and substituting stakeholder analysis for genuine collaboration, as outlined in the Guide, will not suffice. Deliberative democracy must "call into existence" [82] a public partner that can articulate the public's voice in all its diversity and complexity [83].

\subsection{Co-Design the Local SDG Agenda}

In deliberative democracy, the commitment to the public's influence can be demonstrated initially by inviting the local public to set the agenda by prioritising and modifying the SDG targets in a way appropriate to local circumstances and requirements. The public's aspiration to partnership with government can be satisfied by complementing bureaucratic and technocratic expertise with the experience of both "on-the-ground" knowledge and values and priorities that only citizens can bring to the process.

Strong evidence now exists that descriptively representative, deliberative "mini-publics" $[83,84]$ possess the ability to set agendas for achieving sustainability. A mini-public is a microcosm of the wider public. We use an intermediately expansive definition of mini publics of a broadly representative and inclusive sub group of an affected population that engages in structured and facilitated deliberation toward an influential end. One example of a mini-public is a Deliberative Poll [85] implemented in various areas of policy to inform government actions [86]. Often these Deliberative Polls have led to progress toward sustainability in the area of policy being addressed $[87,88]$ as well as shifting citizen attitudes [89].

The authors employed a similar process for the purpose of agenda setting in the city-region of Greater Geraldton, Western Australia [90]. This deliberative poll sought to understand public views on key sustainability challenges facing the city-region. A randomly selected sample of 3000 residents received detailed questionnaires and was invited to attend a "deliberation day" to learn more about the issues. Around 150 randomly sampled community members (stratified by age, gender and geography) participated in this mini-public. Participants filled out the community survey again (to calibrate the results to be representative of the population demographics). Then they listened to different perspectives, cross-examined speakers, discussed the issues raised in small groups and without coming to any decisions, filled out the survey for a final time. The results from the 557 randomly sampled residents who completed their surveys, and around 100 who participated in a one day mini-public, showed resolve for the City to take proactive steps to become carbon neutral, and only increased following the deliberation. This surprised administrators and resulted in a far more ambitious sustainability agenda than originally planned [91].

In a second example of agenda setting in Greater Geraldton, a mini-public of around 250 participants worked in parallel with a multidisciplinary team of around 20 experts over three days to "co-design" a new Statutory Regional Plan to guide future City Region land use planning policies and 
decisions [92]. Around 250 community participants (one third randomly sampled, one third invited stakeholder representatives and one third respondents to broad advertisements) deliberated over three days in small groups using networked computers to help synthesise the ideas of the room and facilitate prioritisation of the most important issues. In parallel, the multidisciplinary expert team created geographical picture plans from the community participants' ideas and priorities [93] that underwent continual modification and prioritisation by the community. Once again surprising officials, the plan prioritised the protection of the region's natural assets and structured more sustainable urban living.

In both instances, the enacting of deliberative democracy principles through these mini-publics resulted in new directions that achieved a greater impact by being integrated into institutional processes with broader purposes in the region. Hence, after two years, the results of over a dozen other deliberative democracy initiatives were incorporated into a City-Region Community Charter and the Local Planning Strategy [92]. In turn, the Community Charter later morphed into the Strategic Community Plan, which drives the funding and operations of the city-region. Though the SDGs had not yet been globally adopted, the challenges that these mini-publics addressed covered the same territory. Our experience with these mini-publics has demonstrated consistently that everyday people do not tend to think in the silo'd categories created by technocrats. Instead, they seem to see and understand the world more holistically, thereby achieving integration of diverse topics without conscious effort at the agenda design level.

\subsection{Co-Implement the Local SDG Agenda}

The SDG Guide does describe a method for planning in a goal-based environment: "backcasting" ("Backcasting" is planning by defining a desired future and looking backwards to identify policies and programs that will logically enable that specified future from the present). While the shift from forecasting to backcasting is admirable, including the integration of collective values with current data and future trends, this does represent only the tip of the implementation iceberg. Implementation also needs to include budget allocation and financing, policy changes, training, regulatory reform, evaluation, progress reporting, and other machinery of government changes. Critically, the legitimacy of government is undermined whenever the authorities try to implement solutions that people believe are made "politically" rather than "on the merits". It suffers as well when there is a "loss of signal" that feeds information back to constituents from officials, and vice versa. Continuous citizen involvement in policy-making, which enables people to feel they've been heard and treated fairly, is essential to sustaining confidence in government.

One example of this co-implementation that has become institutionalised in over 2500 places across the globe is Participatory Budgeting (PB) [94]. PB has demonstrated its ability to change the practice of governments regarding municipal spending [95] and to stimulate local economies, bringing local communities back to life [96]. PB is a family of disparate processes, generally involving local people allocating a pre-determined total (usually around 10 percent of a municipal budget) to projects developed by civic groups. The basic PB process begins with the broader community participating in community assemblies as a first step in engaging groups of residents in developing, discussing, and finally submitting proposals to the local government for costing. These projects are then displayed in public places throughout the community, and people vote for their favourites. The top priorities within the allocated budget are enacted, often with local people assisting in their implementation. Often, local representatives have a role in the scrutiny and monitoring of the process.

With a history of over 20 years in cities, PBs have been recommended by the World Bank [97] for their efficacy in improving health, inequality, social justice, and other non-environmental outcomes [98]. However, it has been argued that this style of PB is not a strongly deliberative experience $[83,99]$ although it scores highly on the principles of influence and inclusion. It has further been suggested, that such deliberation principles are necessary for a fully participatory budgeting experience [96] —and particularly, for the all-encompassing task of implementing the SDGs. A form of PB has been 
developed in Australia that does meet the fuller deliberation standard with the other requirements of deliberative democracy.

In the "Australian PB", members of the public usually allocate 100 percent of a municipal budget $[90,100]$. Municipal budgets are too complex, though, for the usual PB procedure by which local people vote on stakeholder groups' project proposals without deliberation. The increasing demand for services, often with shrinking budgets mitigates against budgetary allocation to long term strategies to achieve goals such as the SDGs. In these circumstances, any PB in which participants wish to allocate funds for one or more SDGs almost certainly will have to meet the requirements of deliberative democratic governance mentioned earlier: distributed power and collaborative decision-making and action; access to information that only a diverse set of participants can supply; and, most important of all, the careful listening, weighing, and balancing that characterise deliberative communication.

Four Australian PBs (all deliberative mini-publics) have been implemented in urban areas: one in Melbourne, Victoria's capital city [101], one in Canada Bay, New South Wales [100], and two in the City-region of Greater Geraldton (CGG) in Western Australia (WA). Each of these PBs illustrated how citizens can integrate multiple SDGs, even strengthening the legitimacy of democratic process, including when tough decisions need to be made, "when the rubber hits the road". The two CGG PBs are described briefly below.

In response to public anger due to large tax increases [102] the municipal government committed to pioneering City-Region Participatory Budgeting [100] on the entire allocation of the local government budget. Two Participatory Budgeting initiatives were established. The participants of both were citizens selected via stratified random sampling by age, gender, cultural background, and residential location by an independent party to constitute a descriptively representative mini-public. The criteria for judging a service or piece of infrastructure were generated by mini-public members through extensive deliberation and endorsement and then calibrated to determine the reliability and validity of their criteria. From the outset, the local government committed to considering all the recommendations of the mini-publics, implementing them where possible, and providing a public explanation if they could not (the maximum degree of influence allowed under local legislation). The first Participatory Budgeting Panel of 30 participants deliberated over four Saturdays to determine the allocation of a ten-year capital works budget of around \$AUD 70 million. The elected Council accepted the Panel's Report's recommendations without change [103]. The second Participatory Budgeting Panel of 40 participants deliberated over eight Saturdays on the range and level of City Region services, allocating 100 percent of the operational budget (over \$AUD 70 million). Once again, the recommendations were accepted as legitimate and used to create the operational budget for that financial year [104]. The process of both Panels involved vigorously cross examining city administration officials and deliberating together to determine the budget allocations using a combination of a Multi Criteria Analysis and 21st Century Deliberation. In each PB Panel, participants pushed achieving a sustainable future to the front and centre in their deliberations and allocations.

Deliberative elements such as reflection and justification in the service of the common good were built into the process through the generation of the Panel's value-based criteria and through the request that participants give reasons and reveal their motivations for each service or improvement to infrastructure they supported. Panel members rated the quality of the deliberations very highly, stating that they understood the issues under discussion very well (97\%); learnt about the issues and got new information very well or quite well (93\%); and heard from people with differing viewpoints very well or quite well (100\%). Table facilitators noted significant contestation and dissent in small group discussions during the phases of clarifying common values and prioritising projects and service.

Significantly, the criteria developed by participants demonstrated their awareness of tension between competing goods, and hence the inescapability of trade-offs-a fact of life typically obscured by categorising costs and benefits as economic, social, or environmental. The criteria developed by these everyday citizens reflected a more thoughtful recognition of conflicts between discrete values and the need to reconcile them than do criteria developed by experts and technocrats. 
In our view, the generation by participants of values-based criteria has several important advantages in deliberative PBs:

- It allocates resources that align with community expectations in a more sophisticated way than an opinion poll, (or a less deliberative PB) which assumes citizens are fully cognisant of their values and do not need to reflect on them, nor on those of others involved, prior to making important decisions.

- Considered deliberation helps people recognise values they hold in common. It also helps them understand and acknowledge values they do not share. Further, deliberation requires people to justify their views of the priority they believe their values ought to be assigned relative to other values. It impresses upon people the inescapability of trade-offs and the need to consider whether the expected benefit is worth the cost in terms of other values that must be deemphasised. Value-based criteria can be weighted to incorporate the relative importance of each to the community.

- Openly discussing and determining the importance of a service or project fosters transparency with regard to participants' interests and motivations. (The scores on each criterion for each project are open to inspection.) In addition, deliberation exerts social pressure on participants to be logically consistent from one project to another. In our experience, such pressure is positive in that it tends to elicit more rigorous thinking from people. This does not mean that other members of the public will necessarily agree with the rationale the mini-public provides. Rather, it means the group's reasoning is more likely to be more internally consistent and to relate clearly to the values and priorities the group recommends.

- Carefully deliberated and weighted criteria with coherent (reasoned) recommendations increase the accountability of participants to each other and to the larger community.

As an example of co-implementation, $\mathrm{PB}$ 's provide good evidence that such collaboration between governments and those affected by government budgets can be effective. Further, with a deliberative component that focusses on the complex values of a community, they can harness all the deliberative democratic principles to address the extra challenge that comes with integrating SDGs in cities.

\subsection{Co-Monitor Progress toward Local SDGs}

Monitoring and evaluation may seem an obvious requirement for evidence-based policy, and essential for integrating and implementing SDGs, but traditionally it has been done poorly, even in the well-resourced developed world [61]. As the Guide notes, it can be an expensive and surprisingly politicised process, and for these reasons we recommend monitoring and evaluation based on deliberative democratic principles. From our experience of mini-publics, including in politicised arenas like land use planning and government budgets, which have demonstrated the governance principles needed for co-implementation, the same principles should be applied to monitoring and evaluation. Representative but nonpartisan citizens have shown their ability to hear from both partial and impartial interest groups on technical matters and integrate this with deliberations on their common values. This supports the claim that they could also make useful and influential recommendations regarding what would be important to measure and how it should be measured. There is some literature to indicate this approach can help reduce disagreement stemming from tension between different SDGs and the values they represent, as well as the disputes over transparency and accuracy that often grow out of deeper worries about substantive policy outcomes. Citizens, stakeholders and government officials can develop monitoring and evaluation procedures that all parties will accept as relevant and accurate [105]. Indeed some case studies have already shown that this has been an effective strategy in SDG implementation [106]. 


\section{Scaling the Model}

To be effective, collaborative problem-solving processes must be representative, deliberative, and influential. While this is more readily achieved when relatively small numbers of people are involved, difficulties arise when the activity is attempted on a much larger scale. Many SDGs can be realised only through policies crafted and implemented beyond the local level of government, to the regional, national and international levels of policy-making. The larger the affected population, the more stakeholders are involved, the more complex are the problems and issues, the more powerful are the political and economic interests seeking to influence decision-makers, and, in consequence, the more difficult it is to resolve disagreements. The Guide itself cites the need for "cross-border cooperation" [51] and "vertical coordination with national and state/regional governments" [51]. Section 3.2 addresses topics such as inter-jurisdictional coordination, and its recommendations are consistent with the literature on these matters. But while such recommendations are helpful $[4,107]$, they provide neither an overall approach nor a set of principles for achieving the SDGs at bigger and bigger scales. The Guide explains what must happen, but not how to make it happen. How, exactly, can a city "break down traditional sector-based governance structures"; encourage "coordination between departments and public sector institutions", align "development priorities across different levels of government", and encourage "mutually beneficial decision-making [while] minimizing trade-offs"? [51]. This is the gap that deliberative democracy governance principles can help to fill, while avoiding the over-prescription of specific steps, likely to be detrimental to the adaptation needed to address wicked problems of this type.

The question that now needs addressing is whether it is feasible to "scale" deliberative democracy principles and to move them from face-to-face conversations among a small number of people to multiple groups and communities? The challenge for deliberative democracy interfacing with the SDGs is to preserve its strengths while addressing effectively the added difficulties created by the need to involve a more numerous, more diverse, more contentious public. It is our contention that to meet this challenge, each of the three key principles of deliberative democracy noted earlier-influence, representativeness, and deliberativeness-will have to be "scaled" successfully in a number of dimensions that challenge sustainability at a global level.

Many observers who otherwise support deliberative democracy point out that the great majority of initiatives undertaken to date have been ad hoc, disconnected, relatively small and hence limited in their impact $[108,109]$. Currently, there is also much theorising in the field to respond to this critique [70]. This article responds to the scaling challenge by asking how it could be feasible to enhance the principles of representativeness, deliberativeness, and influence on SDG decision-making whenever, wherever, and with whomever it occurs. The following description proposes a number of areas that are presenting a challenge to the SDGs currently, and offers suggestions as to where we might look for inspiration that this can be done.

\subsection{Scaling Deliberative Democractic Principles to the Grass Roots from the Top}

Most successful deliberative democracy experiments have been conducted in geographically localised areas [110]. Localised deliberation is consistent with the emphasis on pursuing SDGs "at the grass roots", but the task remains of linking multiple local areas and cities in order to maximise impacts—or to achieve any substantial impact at all. "Vertical" scaling of this sort has been discussed widely [51,111,112]. From our perspective, scaling needs to extend not just to higher levels of political organisation, but beyond the government sector to grassroots organisations affected by the SDGs. Extending beyond government and stakeholders not only increases the legitimacy of agenda setting and implementation, but also improves the decision-making quality by enriching the mix of information, experience, and ideas at the table. It is also clear that strong grass roots/civic support plays an important role in preventing changes in governments from changing this course back to more exclusive top-down control. So far, deliberative democracy has not been widely successful in this sort of scaling as much of its empirical successes have been from the top down direction 
(i.e., either driven through existing governmental deliberations or through mini-publics sponsored by governments). Several less deliberative examples, however, indicate what needs to happen for such initiatives to be ongoing. Participatory Budgeting in Brazil, for example, has outlived radical changes in government, Even when incoming governments tried to abandon or weaken the influence of PBs, the citizens' protest was sufficiently strong that the PBs not only persisted, but persisted in being co-decisional [113]. In another less deliberative example, the Transition Initiatives in urban sustainability in Genk, Belgium, exemplifies how the strong connection between the "top" and the "bottom" supports growth and longevity [114]. Policy-makers, NGOs, and community groups may initiate discussions of new practices, experiments or technologies likely to move currently unsustainable routines toward greater sustainability. But irrespective of who takes the lead, others are invited and even expected to collaborate. The four-year deliberative democracy case study in Greater Geraldton, WA [90] exemplifies how vertical scaling can be supported, but may not be sufficient. Here, an attempt was made to scale vertically-downward-to empower ordinary citizens in developing the Strategic Community Plan. Policy-makers recruited, trained and supported the efforts of "Community Champions" to convene local deliberations. Promising proposals were then fast-tracked for potential funding and implementation to give the deliberations influence. Community proposals developed through online deliberation were treated similarly. However, in the long term, the Champions' efforts and online deliberation faded when given less support; and overall, the civic support for deliberative democracy was not strong enough to stop changes in governance from reverting to more traditional styles of "power over" the citizenry [90].

\subsection{Scaling Deliberative Democratic Principles across Developed and Developing Nations}

Expanding influence into parts of the world where deliberative democracy is less common or non-existent, will increase the chances of meeting the SDGs as a whole. The argument here is that, because the ability to deliberate is universal among human beings, democratic governance procedures and tools can be expected to engage and empower people in ways that existing institutions and practices do not [115]. In turn, just as deliberatively involving ordinary people leads to more effective, implementable policy-making in societies where it is prevalent, involving those people in countries where is it non-prevalent, could secure SDG awareness and policy recommendations more aligned with public values, rather than those of vested interests and government officials [116]. Moreover, as mentioned in Section 1.1, this mode of governance provides a potential mechanism to resolve the clash between some activities of developed nations (such as excessive consumption and arms sales) and the SDG related drives of developing ones (such as responsible consumption and security) [14]. There are examples of the potential for such scaling of influence: The global diffusion of Participatory Budgeting (PB) has been enabled by the World Bank which has lent its mainstream economic support to the promulgation of this initiative by investing millions of dollars in grants and loans in developing nations [97]. Deliberative democracy, predominantly implemented in western countries, is now extending to developing countries, including in Pune, India to improve the liveability of the city [117] as well as elsewhere on the subcontinent [118], and numerous Deliberative Polls that have been held in cities and regions in China over several decades [53].

\subsection{Scaling Deliberative Democratic Principles to More and More Complex Problems}

Deliberative democracy has specialised in dealing with classes of problems of complexity and "wickedness" [90] that have stymied existing governance systems [31]. Hence, it is well-suited to the task of integrating and implementing SDGs, though its ability to deal with the most complex of issues is still to be fully tested. Deliberative democracy mini-publics have demonstrated their ability to address complex issues that are normally the prerogative of government officials and experts. The Australian PBs, allocating 100\% of City budgets, described previously [103,104,119], are a case in point. Participants needed to understand highly complex budgeting, local, state and federal responsibilities and priorities, and then create a system for comparing the costs and benefits 
of revenues and expenditures in contexts of growing demands for resources, constrained by fixed revenues. Similarly, the Danish Board of Technology over a 10-year period utilised mini-publics to resolve highly complex technological issues that involved ethical issues. The recommendations of participants influenced subsequent legislation that dealt with those issues [120,121]. Finally, Citizens Juries have tackled complex issues that governments have not been able to resolve including, nuclear waste [122], river management, and infrastructure spending [84]. Despite these successes, it is still an open question as to whether the complexity of SDGs' wide-ranging goals and multitudes of local values can be usefully dealt with by deliberation techniques as tested thus far.

\subsection{Scaling Deliberative Democratic Principles to All Parts of the Policy Cycle}

Deliberative democracy offers advantages in dealing with problems like integrating and implementing SDGs that require tight feedback loops to incorporate ongoing learnings. Those feedback loops are essential, not just at the stage of devising legislation, but at the stages of planning, implementing, evaluating, and modifying the policy that is adopted. During these stages, the public's informed and considered judgments can be as indispensable as they are when the basic policy is under consideration. To date, unfortunately, we have little experience in scaling to "downstream" or operational/implementation phases [105]. However, with a wicked problem like the SDG implementation, a failure to gather deliberative "wisdom" in the downstream phase of the policy cycle could be catastrophic. It is during the implementation of solutions that the problem tends to shift in response to the intervention, and render ineffective or counterproductive even well-considered and representative plans. This downstream effect is further complicated because it often includes the poorly understood phenomena of how the outcomes of deliberation in one arena or part of a government affect decisions or deliberations in other arenas or structures [123].

\subsection{Scaling Deliberative Democratic Principles over Time through Institutionalisation}

The inclusion of the SDGs in the Agenda for 2030 implies that they will extend through and beyond the careers of many of the people working on them. Hence, scaling deliberative democracy over time will be important. Ideally, these deliberative democracy processes will become "business as usual" in the politics of liberal democratic governments, becoming deeply embedded and permanently institutionalised [70]. There is some evidence that institutionalisation can be accomplished, though success is patchy. Early examples of deliberative democracy initiatives that for a decade or more include the (now defunded) Tuscany Law of Participation, Law 69 [124], and the Danish Consensus Conferences on technological issues [120]. Other ongoing initiatives include Constitutional Conventions in the UK and Europe [125], and the Citizens Initiative Review in Oregon, Colorado, Arizona and Massachusetts [56]. By far, the most prolific forms of deliberative democracy are the Participatory Budgeting initiatives, which have been conducted in over 2500 places across the globe [94]. The experience of the South American PBs suggests that long-term institutionalisation is most likely to occur when the public has had sufficient positive experiences of direct involvement in sharing substantially in the making of decisions, not just being "consulted" (and, of course, where governments have continued to support them). Other factors contributing to the longevity of PBs include the commitment of governments to ensuring that ordinary people remain central to governance as co-responsible and co-decisional actors. This allows processes to evolve rather than simply being repeating in a ritual fashion (two Western Australian initiatives at State and Local Government levels illustrate the value of permitting processes to evolve) $[90,126]$; and ensures that decisions produce results that are concrete and observable, so people can see clear evidence of their participation [113]. From this, we gain some insight into the approaches that might allow implementation of the SDGs on multi decadal timescale. 


\subsection{Scaling Deliberative Democratic Principles for Broader Participation}

Two of the key strengths of deliberative democracy are its legitimacy in a contested space [42] and its epistemic strength in the face of uncertainty [43]. These strengths make deliberative democracy especially valuable in attempting to address the contestability and uncertainty inherent in the task of reconciling SDGs, both with other public goods and with each other. Although efforts have been made to maximise legitimacy $[71,127,128]$, at present deliberative democratic methodologies typically do not reach sufficient numbers of citizens to justify the conclusion that they fully embody the core principle of rule by the demos as well as they could [129].

Most responses to this criticism call for the horizontal scaling of deliberation to include ever-increasing numbers of the public. Scaling "out" to involve greater numbers of people while retaining high quality deliberation can enhance the legitimacy of policy outcomes [130] by increasing diversity, by generating substantive decisions that are more "accurate" [131], and by improving effectiveness through greater access to relevant knowledge [43].

Other theorists [132] argue that a higher level of deliberative participation may not be necessary to access the knowledge and to produce the legitimacy of which highly-functional systems of political representation are capable. Unfortunately, the representative model of government at present does not enjoy high levels of trust and satisfaction. Hence, we contend that a nuanced response combining other tools will be maximally effective. The use of descriptive representation (i.e., stratified random sampling) effected through both deliberative practices such as mini-publics and conventional institutional processes can do much to restore public trust in and satisfaction with representative institutions [133]. This entire governance package can be usefully supplemented with non-deliberative input from surveys, opinion polls, and social media. The recent focus on information technologies and their role in scaling participation in governance does require specific qualification like the cautions that apply to opinion surveys generally [134]. While information technology platforms have been invaluable in soliciting public opinion, to date they have fallen far short in terms of generating carefully deliberated public wisdom $[135,136]$. There have been some attempts to combine online deliberation with mini-publics with some success. For example, 3000 randomly sampled people were invited to work in deliberation teams during Australia's first Citizens Parliament to develop proposals which would form the agenda for the 150-participant mini-public [137].

\subsection{Scaling Deliberative Democratic Principles through Discourse Diversificatioin and Process Quality}

This dimension of scaling focuses on expanding the quality of political communication in terms of its usefulness for a world grappling with the complexity and uncertainty of sustainable development. This is important as an inability to maintain or increase deliberative quality scaling while scaling representativeness and influence, will simultaneously undercut the legitimacy of any outcomes (potentially being seen to be ill-informed or partisan; or supportive of participatory but not deliberative democracy). Scaling deliberativeness can be achieved in two main ways, each method focusing on a different aspect of deliberation:

One way to improve deliberation is to increase the diversity of "discourses" associated with the issue being deliberated [138]. A discourse is defined by Dryzek as " . . a shared way of apprehending the world" through language and a coherent narrative about the way the world functions [139]. Each discourse contains assumptions, which then frame communication and analysis, and dispose people to some decisions and actions rather than others. Provided participants make a good faith effort to understand perspectives other than their own, the quality of deliberation rises in direct proportion to the number of effectively represented discourses. Striving to secure the participation of persons who reflect the full range of discourses present in the population may achieve as much attitudinal diversity as a statistically random sample of that population, without the need to expend the resources required to assemble such a sample.

A second way to improve deliberativeness is by making design and execution interventions that raise expectations for participants' seriousness of purpose, preparation, openness, readiness to learn, 
reflection, desire to cooperate, realism, and other characteristics of pragmatic, public-spirited civic work. For example, it has been observed that, in some groups, participants can be accomplished at reflecting internally on information and values but are unable to move from the personal activity of reflecting to the collective activities of reason-giving, prioritising, and decision-making. Both of these are important markers of the quality of deliberation [72] and should be improved to scale deliberativeness. The authors have had some success in scaling design features that have been shown to be effective at a small scale through the use of a bespoke software platform that encourages these aspects of deliberation. This platform (WhatDoWeThink ${ }^{\mathrm{TM}}$, https://whatdowethink.com/) has been used primarily with medium to large groups of 30-100 s of participants. It is designed specifically to address several of the challenges commonly encountered in public deliberation. The challenges include: giving voice to all ideas, whether they enjoy widespread support within the group or appeal to only a few participants, and preventing minority views from being rejected too quickly or without justification in a rush to "let the majority decide"; stating ideas succinctly in order to ensure inclusion and acknowledgment while avoiding redundancy; ensuring that all participants have a genuine opportunity to question, clarify, defend, and contest every idea while holding all accountable for their beliefs and actions; transcending the mechanical "adding up" of individual preferences while honouring the principles that each person should "count as one, but not more than one" and that the will of the majority should, other things equal, prevail; and setting collective priorities.

\section{Discussion and Conclusions}

The Sustainable Development Goals are visionary, ambitious, all-encompassing and interconnected aspirations for a healthier planet and more peaceful and prosperous lives. Like the Millennium Goals that preceded them, while some successes can be celebrated, overall, our progress towards our desired end result remains far from reach. It is now commonly accepted that we need to find new ways of integrating the SDGs to achieve synergies which could accelerate progress. We know what we need to do, but we're far less clear how we might achieve that. The "how" is made more difficult because we are addressing wicked problems and our usual linear thinking will be inappropriate. However, it is now commonly accepted that the "how" will need to involve partnerships between governments, public and private sectors, the 3rd sector and citizenry, and between nations. The task is enormous and the consequences of failing are dire. This article accepts that we do not have tried and true forms of partnership that can propel us forwards to the change we desire. However, we can look to smaller successes where such partnerships have been successful and then visualize ways to scale them up to greater complexity and out to greater numbers of people and nations.

We begin with clarifying the problem we are addressing-implementing SDGs is a wicked problem - and recognizing that achieving significant movement forward will require us to find ways to integrate them. The recognised need for new partnerships has led us to contend that to achieve this, we need to reform governance-the interactions and decision-making of actors within society to resolve collective problems. The elements of governance we deem to be critical to this reform include finding new ways of eliciting collective value judgements, basing these judgements on diverse inputs, applying deliberative communication, and harnessing distributed and collaborative power and action. The principles underlying such governance are described as deliberation/weighing, representation/inclusion and influence/impactfulness, i.e., deliberative democracy. We apply these governance principles to a model for achieving integrated SDGs in cities that takes the following steps: initiate an inclusive and participatory process of SDG localisation; set the local SDG agenda; plan for SDG implementation; and then monitor SDG progress. However, for this process to move from local to global, from relatively simple to highly complex issues, the model would need to be scaled. We take a more innovative tack in this regard, describing how this could be achieved by scaling deliberative democratic principles in a range of directions that are relevant to global sustainability.

The Former UN Secretary, General Ban Ki Moon, once observed that "our struggle for global sustainability will be won or lost in cities" [140]. Accordingly, our focus has been on cities, in particular 
how new partnerships in governance can create new ways for cities to integrate and implement SDGs. This will entail democratic renewal that values the empowered participation of everyday people to develop the public wisdom needed to bring about transformative change, i.e., deliberative democracy. There is a sound rationale for supporting deliberative democracy as an important pathway to achieving the SDGs, and there are exemplary case studies. However, we recognise that unless we can scale deliberative democracy in terms of influence, representativeness and deliberativeness, as well as scaling vertically, horizontally, and over time, these pathways are likely to be very limited. The key will be not only achieving intermittent successes, but systematic change. It is now time to test whether by scaling deliberative democracy, and doing this systematically, cities would be better armed to take on the SDG challenge.

Author Contributions: Conceptualization, R.W. and J.H.-K.; Methodology, R.W. and J.H.-K.; Analysis, R.W. and J.H.-K.; Investigation, R.W. and J.H.-K.; Data Curation, R.W.; Original Draft Preparation, R.W.; Review \& Editing, R.W. and J.H.-K.; Funding Acquisition, J.H.-K.

Funding: This research received no external funding.

Acknowledgments: The authors would like to acknowledge the contribution of an Australian Government Research Training Program Scholarship in supporting this research.

Conflicts of Interest: The authors declare no conflict of interest.

\section{References}

1. United Nations (UN). World Urbanization Prospects: The 2014 Revision, Highlights. Department of Economic and Social Affairs; United Nations: New York, NY, USA, 2014.

2. United Nations (UN). Transforming Our World: The 2030 Agenda for Sustainable Development; United Nations: New York, NY, USA, 2015.

3. Emas, R. Brief for GSDR 2015-The Concept of Sustainable Development: Definition and Defining Principles; Florida International University: Miami, FL, USA, 2015.

4. Stafford-Smith, M.; Griggs, D.; Gaffney, O.; Ullah, F.; Reyers, B.; Kanie, N.; Stigson, B.; Shrivastava, P.; Leach, M.; O'Connell, D. Integration: The key to implementing the sustainable development goals. Sustain. Sci. 2017, 12, 911-919. [CrossRef]

5. United Nations (UN). Global Indicator Framework for the Sustainable Development Goals and Targets of the 2030 Agenda for Sustainable Development. Available online: https:/ / unstats.un.org/sdgs/indicators/ indicators-list/ (accessed on 1 February 2018).

6. UNHabitat. UN-Habitat for the Sustainable Development Goals. Available online: https://unhabitat.org/ un-habitat-for-the-sustainable-development-goals/ (accessed on 11 December 2017).

7. United Cities and Local Governments (UCLG). The Sustainable Development Goals: What Local Governments Need to Know; United Cities and Local Governments: Barcelona, Spain, 2015.

8. Dobbs, R.; Smit, S.; Remes, J.; Manyika, J.; Roxburgh, C.; Restrepo, A. Urban World: Mapping the Economic Power of Cities; McKinsey \& Company: New York, NY, USA, 2011.

9. Hebbert, M. Cities and Climate Change (Global Report on Human Settlements 2011); 0041-0020; UNHabitat: Nairobi, Kenya, 2012.

10. Horton, R. Why the sustainable development goals will fail. Lancet 2014, 383, 2196. [CrossRef]

11. Grimm, N.B.; Faeth, S.H.; Golubiewski, N.E.; Redman, C.L.; Wu, J.; Bai, X.; Briggs, J.M. Global change and the ecology of cities. Science 2008, 319, 756-760. [CrossRef] [PubMed]

12. Kemp, R.; Parto, S.; Gibson, R. Governance for sustainable development: Moving from theory to practice. Int. J. Sustain. Dev. 2005, 8, 12-30. [CrossRef]

13. Weitz, N.; Carlsen, H.; Nilsson, M.; Skånberg, K. Towards systemic and contextual priority setting for implementing the 2030 agenda. Sustain. Sci. 2018, 13, 531-548. [CrossRef]

14. Sachs, J.; Schmidt-Traub, G.; Kroll, C.; Durand-Delacre, D.; Teksoz, K. SDG Index and Dashboards Report 2017; Bertelsmann Stiftung and Sustainable Development Solutions Network: New York, NY, USA, 2017.

15. Connelly, S. Mapping sustainable development as a contested concept. Local Environ. 2007, 12, 259-278. [CrossRef] 
16. Gunnarsson-Östling, U.; Björnberg, K.E.; Finnveden, G. Using the concept of sustainability to work: Interpretations in academia, policy, and planning. In Sustainable Stockholm: Exploring Urban Sustainability in Europe's Greenest City; Metzger, J., Olsson, A.R., Eds.; Routledge: Abingdon, UK, 2013; pp. 51-70.

17. Griggs, D.; Stafford Smith, M.; Rockström, J.; Öhman, M.C.; Gaffney, O.; Glaser, G.; Kanie, N.; Noble, I.; Steffen, W.; Shyamsundar, P. An integrated framework for sustainable development goals. Ecol. Soc. 2014, 19, 49. [CrossRef]

18. Collste, D.; Pedercini, M.; Cornell, S.E. Policy coherence to achieve the SDGS: Using integrated simulation models to assess effective policies. Sustain. Sci. 2017, 12, 921-931. [CrossRef]

19. Prakash, M.; Teksoz, K.; Espey, J.; Sachs, J.D. Preliminary Us Cities Sustainable Development Goals Index 2017: Achieving a Sustainable Urban America; Sustainable Development Solutions Network: New York, NY, USA, 2016.

20. Nilsson, M.; Griggs, D.; Visbeck, M. Map the interactions between sustainable development goals. Nature 2016, 534, 320-323. [CrossRef] [PubMed]

21. Pradhan, P.; Costa, L.; Rybski, D.; Lucht, W.; Kropp, J.P. A systematic study of sustainable development goal (SDG) interactions. Earths Future 2017, 5, 1169-1179. [CrossRef]

22. Turnpenny, J.; Lorenzoni, I.; Jones, M. Noisy and definitely not normal: Responding to wicked issues in the environment, energy and health. Environ. Sci. Policy 2009, 12, 347-358. [CrossRef]

23. Kowarsch, M.; Garard, J.; Riousset, P.; Lenzi, D.; Dorsch, M.J.; Knopf, B.; Harrs, J.-A.; Edenhofer, O. Scientific assessments to facilitate deliberative policy learning. Palgrave Commun. 2016, 2, 16092. [CrossRef]

24. Haas, P. When does power listen to truth? A constructivist approach to the policy process. J. Eur. Public Policy 2004, 11, 569-592. [CrossRef]

25. Rittel, H.W.; Webber, M.M. Dilemmas in a general theory of planning. Policy Sci. 1973, 4, 155-169. [CrossRef]

26. Head, B.W.; Alford, J. Wicked problems. Adm. Soc. 2015, 47, 711-739. [CrossRef]

27. Conklin, J. Dialogue Mapping: Building Shared Understanding of Wicked Problems; John Wiley \& Sons, Inc.: Hoboken, NJ, USA, 2005.

28. Kanie, N.; Biermann, F. Governing through Goals: Sustainable Development Goals as Governance Innovation; MIT Press: Cambridge, MA, USA, 2017.

29. United Nations Development Program (UNDP). Governance for Sustainable Development: Integrating Governance in the Post-2015 Development Framework; United Nations Development Program: New York, NY, USA, 2014.

30. UPAN. Report of the Expert Group Meeting on Policy Integration in Government in Pursuit of the Sustainable Development Goals; UN: New York, NY, USA, 28-29 January 2015.

31. Briggs, L. Tackling Wicked Problems: A Public Policy Perspective; Australian Public Service Commission: Canberra, Australia, 2007.

32. De Graaf, G.; Van Der Wal, Z. Managing conflicting public values: Governing with integrity and effectiveness. Am. Rev. Public Adm. 2010, 40, 623-630. [CrossRef]

33. Rozema, J.G.; Bond, A.J.; Cashmore, M.; Chilvers, J. An investigation of environmental and sustainability discourses associated with the substantive purposes of environmental assessment. Environ. Impact Assess. Rev. 2012, 33, 80-90. [CrossRef]

34. Mathur, V.N.; Price, A.D.; Austin, S. Conceptualizing stakeholder engagement in the context of sustainability and its assessment. Constr. Manag. Econ. 2008, 26, 601-609. [CrossRef]

35. Sinclair, A.J.; Diduck, A.P.; Vespa, M. Public participation in sustainability assessment: Essential elements, practical challenges and emerging directions. In Handbook of Sustainability Assessment; Morrison-Saunders, A., Bond, A., Pope, J., Eds.; Edward Elgar Publishing: Cheltenham, UK, 2015; pp. 349-374.

36. McPhearson, T.; Parnell, S.; Simon, D.; Gaffney, O.; Elmqvist, T.; Bai, X.; Roberts, D.; Revi, A. Scientists must have a say in the future of cities. Nat. News 2016, 538, 165. [CrossRef] [PubMed]

37. Stocker, L.; Burke, G. A new methodological framework for improving sustainability and climate change governance. In Methods for Sustainability Research; Hartz-Karp, J., Marinova, D., Eds.; Edward Elgar Publishing: Cheltenham, UK; Northampton, MA, USA, 2017; pp. 95-112.

38. Hong, L.; Page, S.E. Groups of diverse problem solvers can outperform groups of high-ability problem solvers. Proc. Natl. Acad. Sci. USA 2004, 101, 16385-16389. [CrossRef] [PubMed] 
39. Bouricius, T. Sortition: Envisaging a new form of democracy that enables decision-making for long term sustainability. In Methods for Sustainability Research; Hartz-Karp, J., Marinova, D., Eds.; Edward Elgar: Cheltenham, UK, 2017.

40. Grint, K. Wicked problems and clumsy solutions: The role of leadership. Clin. Lead. 2008, 1, 54-68.

41. Pope, J.; Petrova, S. Sustainability assessment: A governance mechanism for sustainability. In Methods for Sustainability Research; Hartz-Karp, J., Marinova, D., Eds.; Edward Elgar Publishing: Cheltenham, UK; Northampton, MA, USA, 2017; pp. 142-156.

42. Allegretti, G. Paying attention to the participants' perceptions in order to trigger a virtuous circle. In Hope for Democracy: 25 Years of Participatory Budgeting Worldwide; Dias, N., Ed.; In Loco Association: São Brás de Alportel, Portugal, 2014; pp. 47-63.

43. Landemore, H. Democratic Reason: Politics, Collective Intelligence, and the Rule of the Many; Princeton University Press: Princeton, NJ, USA, 2013.

44. Sala, S.; Ciuffo, B.; Nijkamp, P. A systemic framework for sustainability assessment. Ecol. Econ. 2015, 119, 314-325. [CrossRef]

45. Lang, D.J.; Wiek, A.; Bergmann, M.; Stauffacher, M.; Martens, P.; Moll, P.; Swilling, M.; Thomas, C.J. Transdisciplinary research in sustainability science: Practice, principles, and challenges. Sustain. Sci. 2012, 7, 25-43. [CrossRef]

46. Meadowcroft, J. Who is in charge here? Governance for sustainable development in a complex world. J. Environ. Policy Plan. 2007, 9, 299-314. [CrossRef]

47. Cohen, B.; Winn, M.I. Market imperfections, opportunity and sustainable entrepreneurship. J. Bus. Ventur. 2007, 22, 29-49. [CrossRef]

48. Common, M.; Stagl, S. Ecological Economics: An Introduction; Cambridge University Press: Cambridge, UK, 2005.

49. Biely, K.; Larvoe, N.; Maes, D.; Van Passel, S. Examining the Effect of Market Power on Sustainability: Adding another Market Failure to the Sustainability Discourse. In Proceedings of the 22nd International Sustainable Development Research Society Conference, Lisbon, Portugal, 13-15 July 2016.

50. Rittel, H.W. On the Planning Crisis: Systems Analysis of the "First and Second Generations"; Institut für Grundlagen der Planung IA, Universität Stuttgart: Stuttgart, Germany, 1977.

51. Kanuri, C.; Revi, A.; Espey, J.; Kuhle, H. Getting Started with the SDGS in Cities: A Guide for Stakeholders; Sustainable Development Solutions Network: New York, NY, USA, 2016.

52. Andersson, M. Unpacking Metropolitan Governance for Sustainable Development. A Discussion Paper; UNHabitat and Deutsche Gesellschaft für Internationale Zusammenarbeit (GIZ) GmbH: Eschborn, Germany, 2015.

53. He, B.; Warren, M.E. Authoritarian deliberation: The deliberative turn in Chinese political development. Perspect. Politics 2011, 9, 269-289. [CrossRef]

54. Popa, F.; Guillermin, M.; Dedeurwaerdere, T. A pragmatist approach to transdisciplinarity in sustainability research: From complex systems theory to reflexive science. Futures 2015, 65, 45-56. [CrossRef]

55. Chambers, S. Deliberative democratic theory. Annu. Rev. Political Sci. 2003, 6, 307-326. [CrossRef]

56. Hartz-Karp, J.; Carson, L.; Briand, M. Deliberative democracy as a reform movement. In The Oxford Handbook of Deliberative Democracy; Bächtiger, A., Dryzek, J.S., Mansbridge, J., Warren, M., Eds.; Oxford University Press: Oxford, UK, 2018.

57. Gastil, J.; Richards, R.C. Deliberation. In International Encyclopedia of Political Communication; Mazzoleni, G., Ed.; John Wiley \& Sons: Chichester, UK, 2016.

58. Gutmann, A.; Thompson, D.F. Democracy and Disagreement; Harvard University Press: Cambridge, MA, USA, 1998.

59. Dryzek, J.S. Deliberative Democracy and Beyond: Liberals, Critics, Contestations; Oxford University Press: Oxford, UK, 2002.

60. Carson, L.; Hartz-Karp, J. Adapting and Combining Deliberative Designs; Jossey Bass: San Francisco, CA, USA, 2005; pp. 120-138.

61. Greenhalgh, T.; Russell, J. Evidence-based policymaking: A critique. Perspect. Biol. Med. 2009, 52, $304-318$. [CrossRef] [PubMed]

62. Thompson, D.F. Deliberative democratic theory and empirical political science. Annu. Rev. Political Sci. 2008, 11, 497-520. [CrossRef]

63. Elstub, S. The third generation of deliberative democracy. Political Stud. Rev. 2010, 8, 291-307. [CrossRef] 
64. Fishkin, J. When the People Speak: Deliberative Democracy and Public Consultation; Oxford University Press: Oxford, UK, 2009.

65. Nabatchi, T.; Gastil, J.; Leighninger, M.; Weiksner, G.M. Democracy in Motion: Evaluating the Practice and Impact of Deliberative Civic Engagement; Oxford University Press: Oxford, UK, 2012.

66. Mansbridge, J.; Bohman, J.; Chambers, S.; Estlund, D.; Føllesdal, A.; Fung, A.; Lafont, C.; Manin, B. The place of self-interest and the role of power in deliberative democracy. J. Political Philos. 2010, 18, 64-100. [CrossRef]

67. Pateman, C. Participatory democracy revisited. Perspect. Politics 2012, 10, 7-19. [CrossRef]

68. Suiter, J.; Farrell, D.M.; O'Malley, E. When do deliberative citizens change their opinions? Evidence from the irish citizens' assembly. Int. Political Sci. Rev. 2014. [CrossRef]

69. Farrell, D.; Harris, C.; Suiter, J. The Irish vote for marriage equality started at a constitutional convention. The Washington Post, 5 June 2015.

70. Mansbridge, J.; Bohman, J.; Chambers, S.; Christiano, T.; Fung, A.; Parkinson, J.; Thompson, D.F.; Warren, M.E. A systemic approach to deliberative democracy. In Deliberative Systems; Cambridge University Press: Cambridge, UK, 2012; pp. 1-26.

71. Stevenson, H.; Dryzek, J.S. The legitimacy of multilateral climate governance: A deliberative democratic approach. Crit. Policy Stud. 2012, 6, 1-18. [CrossRef]

72. Dryzek, J. Institutions for the anthropocene: Governance in a changing earth system. Br. J. Political Sci. 2014, 46, 937-956. [CrossRef]

73. Svizzero, S.; Tisdell, C. The post-2015 global development agenda: A critical analysis. J. Self-Gov. Manag. Econ. 2016, 4, 72-94.

74. Jordan, A. The governance of sustainable development: Taking stock and looking forwards. Environ. Plan. C Gov. Policy 2008, 26, 17-33. [CrossRef]

75. Arnstein, S.R. A ladder of citizen participation. J. Am. Inst. Plan. 1969, 35, 216-224. [CrossRef]

76. Nabatchi, T.; Sancino, A.; Sicilia, M. Varieties of participation in public services: The who, when, and what of coproduction. Public Adm. Rev. 2017, 77, 766-776. [CrossRef]

77. Nabatchi, T.; Leighninger, M. Participation scenarios and tactics. In Public Participation for 21st Century Democracy; Nabatchi, T., Leighninger, M., Eds.; John Wiley \& Sons: Hoboken, NJ, USA, 2015; p. 241.

78. Bailey, K.; Blandford, B.; Grossardt, T.; Ripy, J. Planning, technology, and legitimacy: Structured public involvement in integrated transportation and land-use planning in the United States. Environ. Plan. Part B 2011, 38, 447-467. [CrossRef]

79. Weymouth, R.; Hartz-Karp, J. Participation in democratic governance: Closing the gap between satisfaction and expectation. Environ. Plan. C Gov. Policy 2018, forthcoming.

80. Levi, M.; Stoker, L. Political trust and trustworthiness. Annu. Rev. Political Sci. 2000, 3, 475-507. [CrossRef]

81. Dalton, R.J. The social transformation of trust in government. Int. Rev. Sociol. 2005, 15, 133-154. [CrossRef]

82. Benington, J.; Moore, M.H. Conclusions: Looking ahead. In Public Value: Theory and Practice; Benington, J., Moore, M.H., Eds.; Palgrave Macmillan: Basingstoke, UK, 2010; pp. 256-272.

83. Ryan, M.; Smith, G. Defining mini-publics. In Deliberative Mini-Publics: Involving Citizens in the Democratic Process; Grönlund, K., Bächtiger, A., Setälä, M., Eds.; ECPR Press: Colchester, UK, 2014; pp. 9-26.

84. Riedy, C.; Kent, J. Systemic Impacts of Mini-Publics; newDemocracy: Royal Exchange, Australia, 2017.

85. Fishkin, J.S.; Luskin, R.C. Experimenting with a democratic ideal: Deliberative polling and public opinion. Acta Politica 2005, 40, 284-298. [CrossRef]

86. Isernia, P.; Fishkin, J.S. The europolis deliberative poll. Eur. Union Politics 2014, 15, 311-327. [CrossRef]

87. Orrell, A.C.; Homer, J.S.; Bender, S.R.; Weimar, M.R. Energy Policy Case Study_Texas: Wind, Markets, and Grid Modernization; Pacific Northwest National Laboratory (PNNL): Richland, WA, USA, 2016.

88. Fishkin, J.S.; He, B.; Luskin, R.C.; Siu, A. Deliberative democracy in an unlikely place: Deliberative polling in china. Br. J. Political Sci. 2010, 40, 435-448. [CrossRef]

89. Gastil, J.; Bacci, C.; Dollinger, M. Is deliberation neutral? Patterns of attitude change during "the deliberative polls(tm)". J. Public Delib. 2010, 6, 3.

90. Weymouth, R.; Hartz-Karp, J. Deliberative collaborative governance as a democratic reform to resolve wicked problems and improve trust. J. Econ. Soc. Policy 2015, 17, 4.

91. City of Greater Geraldton (CGG). Climate of Opportunity: Community Survey and Deliberative Survey Report; City of Greater Geraldton: Geraldton, WA, USA, 2010. 
92. City of Greater Geraldton (CGG). City of Greater Geraldton Draft Local Planning Strategy; City of Greater Geraldton: Geraldton, WA, USA, 2014.

93. City of Greater Geraldton (CGG). Designing Our City Final Report; City of Greater Geraldton: Geraldton, WA, USA, 2011.

94. Sintomer, Y.; Herzberg, C.; Röcke, A.; Allegretti, G. Transnational models of citizen participation: The case of participatory budgeting. J. Public Delib. 2012, 8, 9.

95. Spada, P. The Economic and Political Effects of Participatory Budgeting; Yale University: New Haven, CT, USA, 2009.

96. Sintomer, Y.; Röcke, A.; Herzberg, C. Participatory Budgeting in Europe: Democracy and Public Governance; Routledge: London, UK, 2016.

97. Goldfrank, B. The World Bank and the globalization of participatory budgeting. J. Public Delib. 2012, 8, 7.

98. Allegretti, G.; Hartz-Karp, J. Participatory budgeting: A methodological approach to address sustainability challenges. In Methods for Sustainability Research; Hartz-Karp, J., Marinova, D., Eds.; Edward Elgar: Cheltenham, UK, 2017.

99. Wampler, B.; Hartz-Karp, J. Participatory budgeting: Diffusion and outcomes across the world. J. Public Delib. 2012, 8, 13.

100. Thompson, N.K. Participatory budgeting-the australian way. J. Public Delib. 2012, 8, 5.

101. Melbourne City Council. City of Melbourne 10 Year Financial Plan People's Panel Report; Melbourne City Council: Melbourne, Australia, 2014.

102. ABCNews. Barnett criticises "unacceptable" rate rise. ABC News, 25 October 2012.

103. City of Greater Geraldton (CGG). Particpatory Budgeting Community Panel 10 Year Capital Works Plan-Recommendations \& Report to the City of Greater Geraldton (30 November 2013); City of Greater Geraldton: Geraldton, WA, USA, 2014.

104. City of Greater Geraldton (CGG). Participatory Budgeting Community Panel Range and Level of Services Final Report (9 April 2014); City of Greater Geraldton: Geraldton, WA, USA, 2014.

105. Bächtiger, A.; Grönlund, K.; Setälä, M. Towards a new era of deliberative mini-publics. In Deliberative Mini-Publics: Involving Citizens in the Democratic Process; Setälä, M., Ed.; ECPR Press: Colchester, UK, 2014; pp. 225-241.

106. Thinyane, M.; Goldkind, L.; Lam, H.I. Data collaboration and participation for sustainable development goals-A case for engaging community-based organizations. J. Hum. Rights Soc. Work. 2018, 3, 44-51. [CrossRef]

107. Hendriks, C.M.; Dryzek, J.S.; Hunold, C. Turning up the heat: Partisanship in deliberative innovation. Political Stud. 2007, 55, 362-383. [CrossRef]

108. Niemeyer, S. Scaling up deliberation to mass publics: Harnessing mini-publics in a deliberative system. In Deliberative Mini-Publics: Involving Citizens in the Democratic Process; ECPR Press: Colchester, UK, 2014; pp. 177-202.

109. Parkinson, J.; Mansbridge, J. Deliberative Systems: Deliberative Democracy at the Large Scale; Cambridge University Press: Cambridge, UK, 2012.

110. Levine, P.; Fung, A.; Gastil, J. Future directions for public deliberation. J. Public Delib. 2005, 1, 3.

111. Bellali, J.; Dellas, E.; Fischer, K.; Strauch-adelphi, L. Sustainable Development Goals, New Urban Agenda and the Urban Nexus: Input Paper; Deutsche Gesellschaft für Internationale Zusammenarbeit (GIZ): Eschborn, Germany, 2016.

112. Niemeyer, S. From the minipublic to a deliberative system: Is scaling up deliberation possible? Delib. Democr. Action 2012, 7-8.

113. Alves, M.L.; Allegretti, G. (In) stability, a key element to understand participatory budgeting: Discussing portuguese cases. J. Public Delib. 2012, 8,3.

114. Gorissen, L.; Spira, F.; Meynaerts, E.; Valkering, P.; Frantzeskaki, N. Moving towards systemic change? Investigating acceleration dynamics of urban sustainability transitions in the Belgian city of Genk. J. Clean. Prod. 2018, 173, 171-185. [CrossRef]

115. Crocker, D.A. Ethics of Global Development: Agency, Capability, and Deliberative Democracy; Cambridge University Press: Cambridge, UK, 2008.

116. Mercier, H. On the universality of argumentative reasoning. J. Cogn. Cult. 2011, 11, 85-113. [CrossRef]

117. Menon, S.; Rapur, S. Deliberative democracy and learning for sustainable mobility in Pune. In Academia and Communities: Engaging for Change; United Nations University: Tokyo, Japan, 2018. 
118. Joseph, T.; Joseph, S.K. Deliberative Democracy: Understanding the Indian Experience; Routledge: London, UK, 2018.

119. Green, M. People's Panel Pitches in to Advise Melbourne City Council Where It Should Spend \$5 Billion. Available online: http:/ / www.theage.com.au/national/peoples-panel-pitches-in-to-advise-melbournecity-council-where-it-should-spend-5-billion-20141202-11y9dn.html (accessed on 10 December 2014).

120. Jensen, C.B. Citizen projects and consensus-building at the Danish Board of Technology: On experiments in democracy. Acta Sociol. 2005, 48, 221-235. [CrossRef]

121. Joss, S. Danish consensus conferences as a model of participatory technology assessment: An impact study of consensus conferences on Danish Parliament and Danish public debate. Sci. Public Policy 1998, 25, 2-22.

122. Carson, L. Learnings from South Australia's Nuclear Fuel Cycle Jury; newDemocracy: Royal Exchange, Australia, 2017.

123. Bachtiger, A.; Wegmann, A. "Scaling up" deliberation. In Deliberative Democracy: Issues and Cases; Elstub, S., Mclaverty, P., Eds.; Oxford University Press: Oxford, UK, 2014.

124. Lewanski, R. Institutionalizing deliberative democracy: The "tuscany laboratory". J. Public Delib. 2013, 9, 10. [CrossRef]

125. Farrell, D. The 2013 Irish constitutional convention: A bold step or a damp squib? In 75 Years of the Constitution of Ireland: An Irish-Italian Dialogue; Ferrari, G., O’Dowd, J., Eds.; Clarus: Dublin, Republic of Ireland, 2014; pp. 292-305.

126. Hartz-Karp, J. A case study in deliberative democracy: Dialogue with the city. J. Public Delib. 2005, 1, 6.

127. Raphael, C.; Karpowitz, C.F. Good publicity: The legitimacy of public communication of deliberation. Political Commun. 2013, 30, 17-41. [CrossRef]

128. Richards, R.C.; Gastil, J. Symbolic-cognitive proceduralism: A model of deliberative legitimacy. J. Public Delib. 2015, 11, 3.

129. Chambers, S. Rhetoric and the public sphere: Has deliberative democracy abandoned mass democracy? Political Theory 2009, 37, 323-350. [CrossRef]

130. Smith, G. Democratic Innovations: Designing Institutions for Citizen Participation; Cambridge University Press: Cambridge, UK, 2009.

131. Kao, A.B.; Couzin, I.D. Decision accuracy in complex environments is often maximized by small group sizes. Proc. R. Soc. B 2014, 281, 20133305. [CrossRef] [PubMed]

132. Hennig, B. The End of Politicians: Time for a Real Democracy; Unbound: London, UK, 2017.

133. Gastil, J.; Richards, R.C.; Knobloch, K.R. Vicarious deliberation: How the Oregon Citizens' Initiative Review influenced deliberation in mass elections. Int. J. Commun. 2014, 8, 62-89.

134. Dryzek, J.S. The mismeasure of political man. J. Politics 1988, 50, 705-725. [CrossRef]

135. Wright, S.; Street, J. Democracy, deliberation and design: The case of online discussion forums. New Media Soc. 2007, 9, 849-869. [CrossRef]

136. Hartz-Karp, J.; Sullivan, B. The unfulfilled promise of online deliberation. J. Public Delib. 2014, 10, 16.

137. Sullivan, B.; Hartz-Karp, J. Grafting an online parliament onto a face-to-face process. In The Australian Citizens' Parliament and the Future of Deliberative Democracy; Carson, L., Gastil, J., Hartz-Karp, J., Lubensky, R., Eds.; Pennsylvania State University Press: University Park, PA, USA, 2013.

138. Dryzek, J.; Niemeyer, S. Discursive representation. Am. Political Sci. Rev. 2008, 102, 481-493. [CrossRef]

139. Dryzek, J. The Politics of the Earth: Environmental Discourses; Oxford University Press: Oxford, UK, 2013.

140. United Nations (UN). "Our Struggle for Global Sustainability Will Be Won or Lost in Cities", Says Secretary-General, at New York Event. 2012. Available online: https://www.un.org/press/en/2012/ sgsm14249.doc.htm (accessed on 1 February 2018).

(C) 2018 by the authors. Licensee MDPI, Basel, Switzerland. This article is an open access article distributed under the terms and conditions of the Creative Commons Attribution (CC BY) license (http:/ / creativecommons.org/licenses/by/4.0/). 